Transportation Research Forum

Right-of-Way Acquisition and Property Condemnation: A Comparison of U.S. State Laws Author(s): Shadi Hakimi and Kara M. Kockelman

Source: Journal of the Transportation Research Forum, Vol. 44, No. 3 (Fall 2005), pp. 45-58

Published by: Transportation Research Forum

Stable URL: http://www.trforum.org/journal

The Transportation Research Forum, founded in 1958, is an independent, nonprofit organization of transportation professionals who conduct, use, and benefit from research. Its purpose is to provide an impartial meeting ground for carriers, shippers, government officials, consultants, university researchers, suppliers, and others seeking exchange of information and ideas related to both passenger and freight transportation. More information on the Transportation Research Forum can be found on the Web at www.trforum.org. 


\section{Right-of-Way Acquisition and Property Condemnation: A Comparison of U.S. State Laws}

Recommendations for improvements in U.S. right-of-way (ROW) acquisition processes should consider the environmental, social, political, and economic characteristics of individual states. These characteristics are reflected in state statutes and constitutions, which place restrictions on ROW staff in applying recommended strategies. This work compares state condemnation statutes, noting their weaknesses and strengths. It recommends modifications to current laws to expedite the acquisition process, minimize cost, and build property owners 'trust in government. It also examines how various factors are statistically significant in predicting state condemnation rates.

\section{by Shadi Hakimi and Kara M. Kockelman}

\section{INTRODUCTION}

In a survey conducted by the National Cooperative Highway Research Program (NCHRP), 11 states described state, local, or federal requirements as barriers to rapid acquisition of right-of-way (ROW) (NCHRP 2000). Federal and state laws affect ROW acquisition and related practices and should be considered when developing strategies to improve the quality of the process. While the Uniform Relocation Assistance and Real Property Acquisition Policies Act of 1970 (42 USC 61) and its related regulations (hereafter called the Uniform Act) are the primary federal legislation controlling ROW practice, each state has corresponding laws, some of which are more restrictive than the Uniform Act (NCHRP 2000).

This paper examines key ROW laws for all 50 states and the District of Columbia. Emphasis is placed on rules of real estate acquisition and excludes those of project development, utility relocation, and relocation assistance programs. To identify these key laws, a survey of the literature related to ROW acquisition was performed. The literature addresses amendments to the state ROW laws proven to significantly influence the process, formal procedures required during ROW acquisition for federal projects, and best ROW practices and strategies (developed to assist ROW administrators in the different stages of acquisition). Studies of distinguished state
DOT practices are plentiful, but very few have focused on state ROW laws. These laws may impose restrictions on ROW administrators when applying commonly recommended strategies. In addition, the impact of state political, environmental, economic, and social characteristics on real property condemnation rates has not been investigated previously.

To fill these gaps in the literature, this work compares and contrasts state statutes for ROW acquisition, noting their associated weaknesses and strengths. It recommends modifications to current laws to expedite the acquisition process, minimize cost, and build property owners' trust in government actions. Furthermore, it describes how state characteristics impact condemnation rates. ROW acquisition statutes were reviewed and analyzed from several sources, including legal search engines and state DOT websites. Data sets on ROW acquisition and state characteristics were obtained from the FHWA and the U. S. Census and then analyzed.

\section{BACKGROUND}

ROW acquisition for highway and transportation projects can be very expensive, time consuming, and socially sensitive. The federal government spent nearly \$1 billion for ROW in fiscal year 1999 , at an average federal cost of $\$ 36,400$ per acquired parcel (FHWA 2003). These ROW costs represent $4 \%$ of federal highway funding (AASHTO 2002). While project plans, surveys, and construction have relatively finite timelines, 
property acquisition can be much lengthier than expected, primarily because of the condemnation process (NCHRP 2000). During ROW acquisition, transportation agencies are confronted by human problems and a complex legal system. It is important to gain the public's trust in transportation planning and the ROW acquisition process.

An agency may make offers relying on first-class appraisal methods, acquisitions may be administratively settled for amounts above appraised values, and property owners may receive the best possible relocation assistance. Even then, the owners may not be quite satisfied; "loss" of one's property is a serious affair (Burnside 1996). ROW staff is further challenged by what generally is a series of complex statutes, rules, and regulations. They may confront reasonable and logical customer complaints, but may not be able to meditate them because of statute provisions. Of course, changing statutes requires time-consuming legislation, and there are no guarantees that revised provisions will resemble what staff have requested and/or envisioned (Burnside 1996). With all these challenges, it is difficult to create a quality assurance goal and strategy for ROW acquisition. In addition, quality is a constantly evolving concept, unique to every organization. Strategies used by one agency may not work for others (Burnside 1996).

The federal government remains concerned about the acquisition of real property for federally assisted projects to: (1) meet the Fifth Amendment mandates of due process and just compensation, (2) acquire property without delaying public projects, and (3) ensure that public dollars are spent in an appropriate fashion (USDOT 2002). Therefore, public satisfaction, time and cost are important performance indicators for ROW agencies. Inefficient acquisition and negotiation processes delay projects, increase costs, and disappoint the public. There are trade-offs, of course. For instance, agencies may start condemnation proceedings to expedite acquisition if extended negotiations are expected to cause significant project delays. Condemnation proceedings can result in higher acquisition costs and usually indicate an owner's dissatisfaction with agency actions.
A useful indicator of time, cost, and customer satisfaction in ROW acquisition is the agency's rate of property condemnation. The condemnation rate is the fraction of parcels acquired through the power of eminent domain. If the acquiring agency and property owner cannot reach an agreement, the agency is legally permitted to acquire the property through its power of eminent domain by filing its case with the appropriate state or federal agency (USDOT 2002).

Condemnation proceedings are to be avoided when possible because they often delay project plans, increase acquisition costs, and reflect a lack of public trust in government actions (USDOT 2003). Lower condemnation rates generally are desired, although at times condemnation may result in faster and/or less costly acquisition (USDOT 2003). Although such cases do exist, where an agency begins condemnation proceedings to expedite acquisition, such actions are usually out of necessity to meet stringent project timelines. Under the Uniform Act (specifically, 49 CFR 24 of the implementing federal regulations), agencies must first exhaust all efforts to reach amicable agreements with the property owner through negotiations. Thus, if early condemnation proceedings occur often, the agency is not abiding by the Uniform Act and/ or state laws are restricting ROW staff actions.

Recognizing the value of this single, simple statistic, this study employs state condemnation rates as performance indicators for comparing and evaluating state ROW statutes. The remainder of this paper is structured as follows. First, key ROW laws are identified via a review of amendments to the state ROW laws and federal acquisition regulations in the next two sections. Then, the data sets used for types of analysis are presented. These analyses entail a grouping and comparison of states based on their ROW requirements and condemnation rates, and a statistical model of condemnation rates based on various state characteristics. The final section summarizes the important findings from this study and highlights their implications for ROW acquisition law and practice. 


\section{Influential Amendments to State ROW Laws}

The U.S. Constitution and almost all state constitutions regulate the power of government to acquire private property and restrict private property rights. Typically, property taking or acquisition results in one of two legal actions. The first is condemnation proceedings, where the government admits it is taking a property and agrees to pay the owner "just compensation." The second is when the government encroaches upon a private property interest but denies any taking. Hence, it falls to the property owner to file suit against the government an "inverse condemnation" action, seeking compensation for an unacknowledged exercise of eminent domain (Meltz et al. 1999). As discussed below, statutes on compensable items, uneconomic remnants, and other key areas of ROW acquisition vary across states and their transportation agencies.

States usually determine compensable items through ROW statutes or previous court cases (Meltz et al. 1999). The extent of state law flexibility on compensable items varies across the United States and reveals the value each state places on the rights of individual ownership. Detailed state laws on compensable items are used by ROW staff and their consultants in the property appraisal process. When these laws are properly applied, inverse condemnation cases and condemnation rates are reduced.

According to the Uniform Act, if the owner of a property is left with an uneconomic remnant as a result of partial acquisition, the head of the involved federal agency must offer to acquire that remnant. Each state's definition and determination of uneconomic remnants is unique. Furthermore, state law may differ from federal law in allowing use of eminent domain power for acquisition of such remnants. State provision of law that allows this technique through negotiation or condemnation reduces condemnation rates and enhances the acquisition process. As an example, after the 1956 passage of The National Interstate and Defense Highways Act (also known as the Federal Highway Act), the state of Illinois could acquire only the land actually needed for construction of its interstate highways (Levin 1963). In 1957, its state legislature decided to permit purchase of uneconomic remnants (rather than application of eminent domain) if severance damages were estimated to exceed purchase costs. This new law facilitated ROW acquisition for that state in development of its Interstate highways (Levin 1963). Allowing the governmental agencies to acquire the uneconomic remnants (through negotiations or power of eminent domain) and providing them with sufficient funding to do so can significantly reduce the possibility of litigation and thus reduce condemnation rates.

New York State's Division of Highways struggled with a provision in its state constitution that prohibited the taking of private property for public use until final just compensation had been ascertained and paid (Levin 1963). The 1957 session of the state's legislature authorized a "quick taking" procedure, when urgent circumstances for a highway's construction could be shown (Levin 1963). New York has made use of this law in many instances, expediting the delivery of required ROW (Levin 1963). Judicious use of this technique is advised, however, to avoid its abuse, and any adverse effect on the nature of acquisitions - and consequently condemnation rates.

Another option involves the early acquisition of land for expected, future public use to avoid interim development and minimize later acquisition costs. Meltz et al. (1999) finds that such acquisition is justified five to 10 years in advance. However, state highway authority approval and state revolving funds are needed; and the agency must be assured of federal reimbursement, if a federal-aid highway is involved. Early land-taking laws significantly vary across the United States and help reduce condemnation rates.

The nature of early negotiations can be a key issue in condemnation proceedings (Netherton 1963). Some states require that there be an attempt to negotiate in good faith, others require only a failure to agree, and some require no negotiations at all. Whatever the rule, it is best in all cases that the agency's ROW administrators/negotiators be in a position to make an offer to owners and be familiar with the elements of that offer in early negotiations (Netherton 1963). A negotiator's preliminary visits and interactions with owners 
influence owner attitudes throughout the subsequent acquisition proceedings (Netherton 1963). A statutory emphasis on informed and proactive negotiations can significantly reduce condemnation rates.

Another key acquisition technique is land consolidation, where remainder lands are purchased on either side of a new highway and property consolidations are facilitated for owners (AASHTO 2002). Irregularly shaped and isolated remainders are not useful to property owners. Most owners prefer to have all property on one side of a facility, for purposes of property management, including farming. Land consolidation requires more agency intervention and owner coordination, but reduces damages and property owner dissatisfaction. It tends to be most useful when acquiring rural lands and when there are a number of remainders belonging to multiple owners (Lindas 1963).

Land exchange is another technique, where properties outside the required acquisition area are purchased, and then exchanged for lands needed for the project. This requires explicit agency authority, and is relatively rare. If wellregulated and not abused, land exchange can relieve many acquisition issues (Lindas 1963).

As discussed above, state ROW statutes on compensable items, uneconomic remnants, quick and early takings, land consolidation, and land exchange vary across states and their transportation agencies. These are all expected to impact condemnation rates. Such statutes are compared across states later in the paper.

\section{The Uniform Act: Its Provisions and Impacts on Condemnation Rates}

The Uniform Act only applies to federally-aided projects (49 CFR Part 24). State laws must be in accordance with the Uniform Act unless required permission is obtained (49 CFR Part 24). This section reviews federal laws for ROW acquisition, as outlined in the Uniform Act. It emphasizes issues that are flexible and thus determined more by state laws. These include early public involvement, sharing of appraisal information, coverage of litigation expenses, negotiations, and quick taking.
Project Development. Public involvement is an essential part of the project development process. It is intended to inform the public of the potential impacts of the project. This helps agencies ascertain support for a project and, more specifically, support for each alignment (FHWA 2000). Depending on state provisions for the use of public hearings in selecting design alignments, this function can noticeably assist in minimizing cost, expediting the process, and satisfying the public's need for input because hearings allow the agency to become acquainted with public concerns (NCHRP 2000). And, ideally, public opinion plays an important role in final alignment selection.

\section{Property Appraisal and the Determination} of Just Compensation. Private property appraisal, and its review and approval by the acquiring agency, are cornerstones for provision of just compensation (USDOT 2001). Before an agency can begin negotiations with property owners, the Uniform Act requires formal appraisal and its approval as the basis for any offer of just compensation. The Act waives the appraisal requirements in cases of low-value, straightforward acquisitions, up to $\$ 2,500$, and permits state agencies to raise this limit further, to $\$ 10,000$ (USDOT 2001). Higher limits result in lower condemnation rates (NCHRP 2000).

The level of appraisal details included in the report and shared with property owners also can assist in avoiding litigation/condemnation proceedings. Some state laws do not require the acquiring agency to share their detailed appraisal reports with owners, though this may lead owners to distrust the agency's determination of just compensation.

Negotiation versus Condemnation. The next step of the acquisition process is negotiation. After an agency delivers the written offer of just compensation for property purchase and begins negotiations with the owner (or his/her representative), it must provide the owner a reasonable amount of time to reject or accept the offer (USDOT 2002). The time that is given to the property owner to consider the offer impacts condemnation rates: higher time spans result in higher condemnation rates (NCHRP 
2000). This is probably because (1) more time allows owners to investigate other offers and acquire legal representation and (2) in cases where project timelines are tight, more time for owners may result in a need for more "quick takings" (if allowed).

Almost $80 \%$ of all ROW acquisitions are settled without initiating condemnation proceedings (USDOT 2002). Ideally, all ROW should be acquired via negotiation, rather than condemnation and litigation. This approach reflects the Uniform Act's requirement that agencies “...make every reasonable effort to acquire expeditiously real property by negotiation." The time and cost $^{1}$ expended in acquiring property through litigation is substantial for the agency and property owners. It also results in adversarial interactions between the agency and property owners and further burdens an already-overloaded court system (USDOT 2003).

However, the appraisal process is imperfect. While structured and professional, appraisal of land and improvements is by nature subjective and imprecise. Moreover, property owners may expect compensation offers to be biased low. Given these factors, it can be helpful to allow for different, non-litigious acquisition strategies if agreement cannot be reached through the normal negotiation process (USDOT 2002).

One of these strategies is the administrative settlement and occurs prior to the agency's initiation of its condemnation authority. It typically is more than the agency's approved offer of just compensation but not excessively so; its value may implicitly recognize the expected cost of litigation and the potential cost of project delays. Administrative settlements generally are considered when reasonable efforts to negotiate an agreed acquisition price have failed but there appears to be the potential for agreement. Alternative dispute resolution (ADR) techniques, such as mediation, are another approach that allows property owners and agencies to turn to a third party for resolution of their disagreement. The use of administrative settlements and ADR techniques can significantly reduce condemnation rates. Another option is the legal settlement, a resolution of the dispute after condemnation has been filed but prior to a court award (USDOT 2002). Nearly $30 \%$ of all ROW acquisition cases filed for eminent domain proceedings are legally settled prior to the court award (USDOT 2002).

The USDOT (2001) recommends that administrative settlements and ADR be considered prior to initiation of a legal settlement or condemnation. The importance that state statutes place on alternative negotiations and the flexibility a state provides in employing such strategies can impact condemnation rates.

\section{DATA ASSEMBLY}

As described above, existing literature regarding ROW acquisition does not analyze variations in condemnation rates across states nor compare and contrast state laws. The data acquired and analyzed here intends to address these significant gaps in the literature.

State characteristics for the year 2000 and ROW acquisition data for the years 1996 through 2002 were obtained from the FHWA (http://www.fhwa.dot.gov/realestate/stats/) and the U.S. Census (http://www.census.gov/ $\mathrm{prod} / \mathrm{www} /$ statistical-abtract-04.html) websites. The state characteristics include income per capita, rural and urban populations, number of registered Republicans, rural and urban highway mileages, educational levels, and percentage of land owned by the federal government. The seven years of condemnation rates were averaged to produce more stable, longer-term state-based condemnation rates. These data are shown in Table 1.

State ROW statutes in each state's general laws or constitution were accessed on the "www.findlaw.com" website, which provides all current federal and state laws and regulations. The LexisNexis database facilitated more narrow searches on specific ROW issues addressed in each state's constitution, general body of laws, and court cases.

In addition, a survey of states ROW administrators conducted by Kockelman et al. (2003) was used as an additional source of ROW-related statutes. 


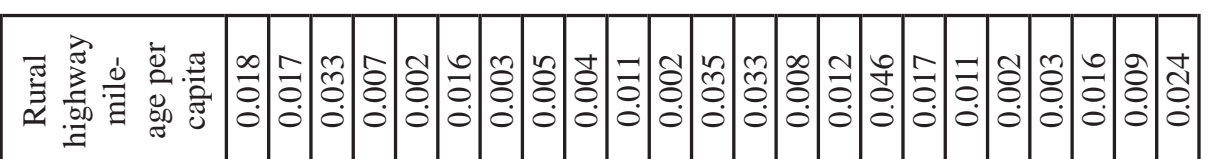

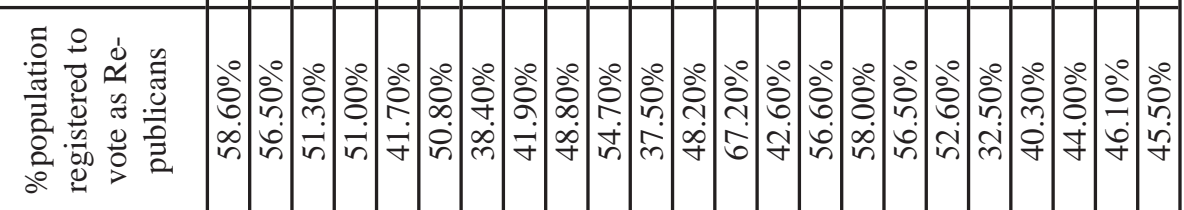

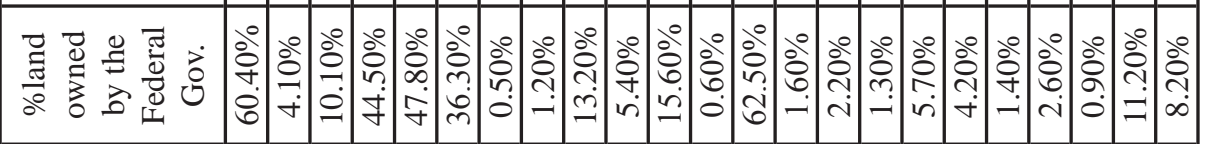

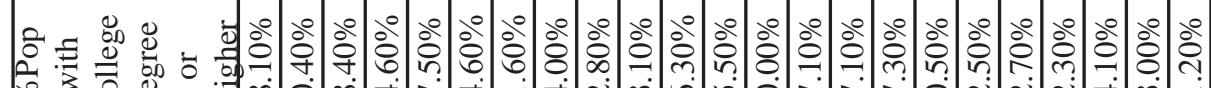

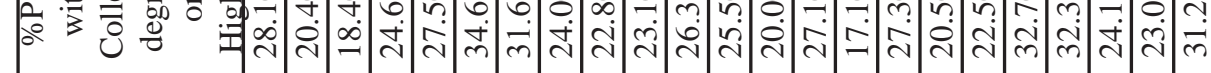

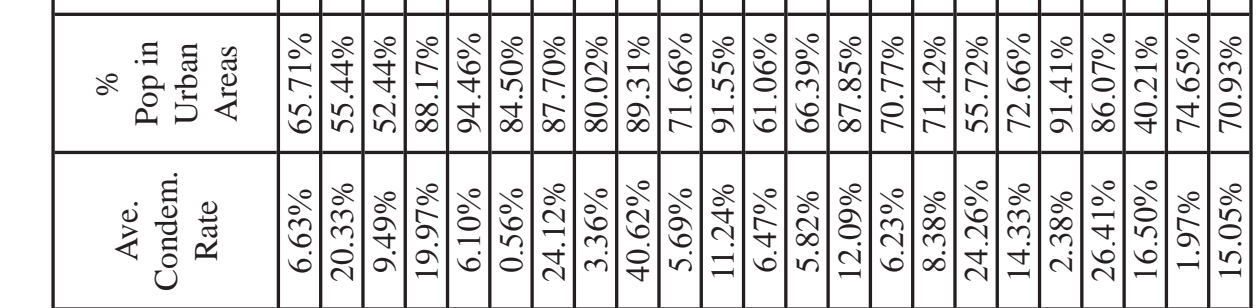

\begin{tabular}{|c|c|c|c|c|c|c|c|c|c|c|c|c|c|c|c|c|c|c|c|c|c|}
\hline 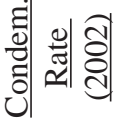 & $\mid \begin{array}{c}0 \\
0 \\
0 \\
\dot{\nabla} \\
\dot{\nabla}\end{array}$ & $\begin{array}{l}0 \\
0 \\
0 \\
+ \\
\text { t. } \\
-1\end{array}$ & $\begin{array}{l}0 \\
0 \\
0 \\
\infty \\
0 \\
0\end{array}$ & $\left|\begin{array}{l}\circ \\
\stackrel{\circ}{\alpha} \\
\grave{b} \\
\end{array}\right|$ & $\begin{array}{l}\stackrel{0}{\circ} \\
\text { ᄋे } \\
\text {-1 }\end{array}$ & 吕 & 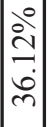 & $\left|\begin{array}{lll}0 & \\
0 \\
0 \\
\vdots \\
1 \\
ن\end{array}\right|$ & & 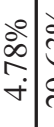 & & $\begin{array}{l}0 \\
0 \\
0 \\
\\
\end{array}$ & \begin{tabular}{l|l}
0 \\
0 \\
0 \\
0 \\
0
\end{tabular} & 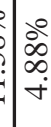 & 文 & $\left|\begin{array}{c}0 \\
0 \\
0 \\
n \\
0 \\
2\end{array}\right|$ & $\begin{array}{l}0 \\
0 \\
0 \\
\infty \\
\infty\end{array}$ & & $=\frac{8}{8}$ & ڤें & مे \\
\hline 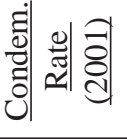 & 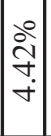 & $\begin{array}{l}\text { ठे } \\
\text { ฟุ. } \\
\text { ஸे }\end{array}$ & 吕 & $\mid \begin{array}{c}0 \\
0 \\
0 \\
+ \\
\dot{d}\end{array}$ & $\begin{array}{l}0 \\
\infty \\
\infty \\
0 \\
0\end{array}$ & 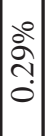 & 离 & $\left.\mid \begin{array}{ccc}0 & \\
0 \\
0 \\
1 \\
1 \\
1\end{array}\right]$ & $\begin{array}{l}\stackrel{\circ}{ } \\
\vec{n} \\
\text { लें }\end{array}$ & $\begin{array}{l}\circ \\
\text { के } \\
\infty \\
\infty\end{array}$ & 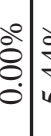 & فं & \begin{tabular}{c|c}
0 \\
0 \\
0 \\
0
\end{tabular} & : & 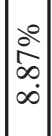 & $\mid$ & $\begin{array}{l}\stackrel{0}{\circ} \\
\exists \\
\exists\end{array}$ & & ஸे & 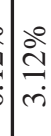 & 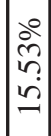 \\
\hline 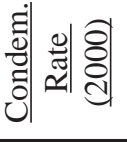 & $\mid \begin{array}{l}0 \\
\infty \\
\alpha \\
0 \\
0\end{array}$ & 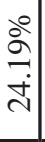 & 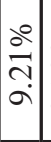 & $\mid \begin{array}{l}\stackrel{0}{ } \\
\infty \\
\sim \\
\stackrel{2}{2}\end{array}$ & 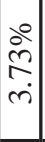 & 吕 & 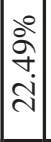 & $\mid \begin{array}{c}0 \\
\vdots \\
0 \\
0 \\
0 \\
0\end{array}$ & $\begin{array}{l}\text { oे } \\
\text { ठे } \\
\infty \\
\text { mे }\end{array}$ & $\begin{array}{c}0 \\
\stackrel{0}{0} \\
\infty \\
\infty\end{array}$ & 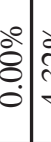 & $\begin{array}{l}\circ \\
\text { aे } \\
\text { oे }\end{array}$ & \begin{tabular}{lll}
0 \\
0 \\
\hdashline \\
\hdashline
\end{tabular} & \begin{tabular}{l}
0 \\
$\vdots$ \\
0 \\
\hdashline \\
\hdashline \\
\hdashline
\end{tabular} & 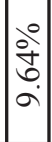 & 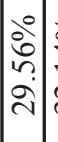 & 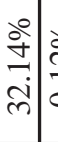 & & ทे & مُ & 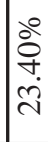 \\
\hline 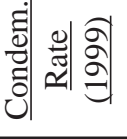 & $\mid \begin{array}{l}0 \\
\grave{2} \\
\infty \\
\infty\end{array}$ & 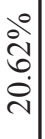 & $\begin{array}{l}0 \\
0 \\
0 \\
n \\
n \\
-1\end{array}$ & 吕 & 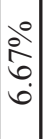 & $\mid \begin{array}{l}0 \\
0 \\
0 \\
0 \\
0\end{array}$ & 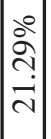 & 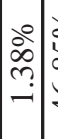 & $\begin{array}{l}0 \\
0 \\
\infty \\
\infty \\
0 \\
+\end{array}$ & $\frac{0}{\stackrel{0}{2}}$ & 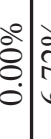 & 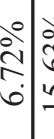 & 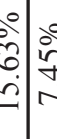 & $\left\{\begin{array}{l}0 \\
0 \\
\vdots \\
i \\
i\end{array}\right.$ & $\mid \begin{array}{l}0 \\
\stackrel{0}{0} \\
\infty \\
\infty \\
\infty\end{array}$ & 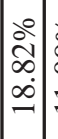 & $\begin{array}{l}\text { த̊ } \\
\text { ○े } \\
-1\end{array}$ & 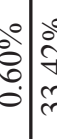 & 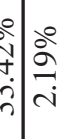 & & $\begin{array}{l}0 \\
0 \\
0 \\
0 \\
0\end{array}$ \\
\hline 竎 & $\begin{array}{l}\circ \\
\dot{m} \\
\sigma \\
\text { ले }\end{array}$ & 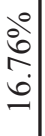 & $\begin{array}{l}0 \\
0 \\
0 \\
0 \\
\end{array}$ & 六 & 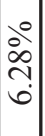 & 递 & $\mid$\begin{tabular}{c}
0 \\
$\dot{0}$ \\
\hdashline \\
$\dot{0}$ \\
\end{tabular} & $\left(\begin{array}{l}0 \\
0 \\
0 \\
0 \\
0\end{array}\right.$ & $\begin{array}{l}\text { ¿ें } \\
\text { o. } \\
\dot{0} \\
+\end{array}$ & \begin{tabular}{l|l} 
& 0 \\
0 & \\
0 & \\
$\dot{\sigma}$ & \\
&
\end{tabular} & $\begin{array}{l}0 \\
8 \\
8 \\
0 \\
0 \\
m\end{array}$ & $\begin{array}{l}0 \\
\vdots \\
\vdots \\
0\end{array}$ & 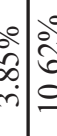 & $\begin{array}{l}\text { iे } \\
\text { iे } \\
\text { iे }\end{array}$ & مิ & $\mid \begin{array}{c}0 \\
0 \\
0 \\
0 \\
- \\
-1\end{array}$ & 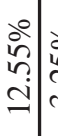 & & 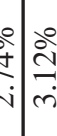 & $\mid \begin{array}{l}0 \\
\vdots \\
0 \\
0 \\
0\end{array}$ & 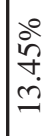 \\
\hline 矛 & $\begin{array}{l}\circ \\
\cdots \\
= \\
= \\
=\end{array}$ & 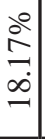 & 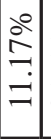 & خें & $\begin{array}{c}\stackrel{0}{2} \\
\infty \\
\text { ले }\end{array}$ & 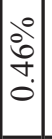 & $\mid \begin{array}{c}0 \\
\stackrel{0}{b} \\
\dot{0} \\
-1\end{array}$ & 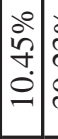 & 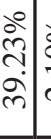 & 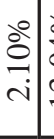 & 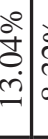 & 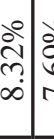 & ל. & iे & 号 & $\left|\begin{array}{c}0 \\
\dot{5} \\
m \\
\dot{m} \\
\dot{m}\end{array}\right|$ & 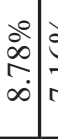 & & 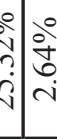 & ì & 尊 \\
\hline 竎 & $\frac{0}{0}$ & $\begin{array}{l}\stackrel{0}{ } \\
\infty \\
\infty \\
\stackrel{\sim}{-1}\end{array}$ & 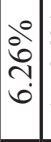 & $\mid \begin{array}{c}0 \\
8 \\
0 \\
a \\
\end{array}$ & $\begin{array}{l}\text { वे } \\
\text { mे } \\
\text { ஸे }\end{array}$ & $\mid$\begin{tabular}{c}
0 \\
$\infty$ \\
\hdashline \\
-1 \\
-1
\end{tabular} & $\mid \begin{array}{l}\circ \\
\infty \\
\infty \\
\vdots \\
-1\end{array}$ & $\left.\mid \begin{array}{c}0 \\
8 \\
\hdashline \\
-1 \\
\dot{-1}\end{array}\right)$ & \begin{tabular}{l}
$\stackrel{0}{\circ}$ \\
\multirow{2}{*}{} \\
$\dot{m}$ \\
mे
\end{tabular} & $\begin{array}{l}0 \\
\hat{c} \\
\hat{\sigma} \\
\dot{+}\end{array}$ & $\begin{array}{l}0 \\
8 \\
0 \\
0\end{array}$ & 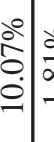 & 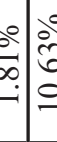 & ì & 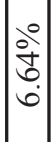 & $\mid \begin{array}{c}0 \\
0 \\
0 \\
0 \\
0 \\
0 \\
m\end{array}$ & 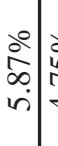 & 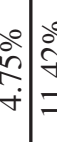 & ปे & $\begin{array}{l}\stackrel{\circ}{\infty} \\
\stackrel{\infty}{0} \\
\text { mे }\end{array}$ & $\stackrel{\stackrel{0}{N}}{\stackrel{\circ}{0}}$ \\
\hline & $\frac{1}{4}$ & 学 & | & 齐 & ن & ن & U & 됩 & 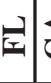 & త & $\overline{\mathbf{I}}$ & 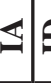 & $\theta=$ & Z & $\begin{array}{l}n \\
\Sigma\end{array}$ & $\underline{2}$ & 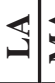 & $\leq$ & $\geqslant \mid$ & $\Sigma$ & \\
\hline
\end{tabular}




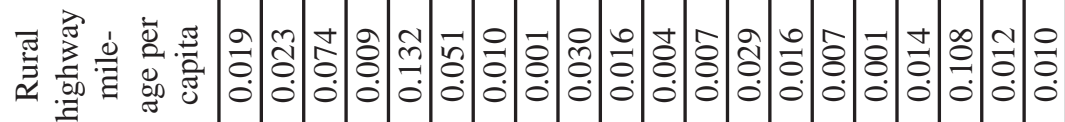

응 워

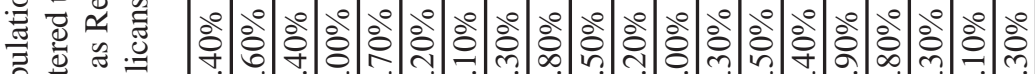

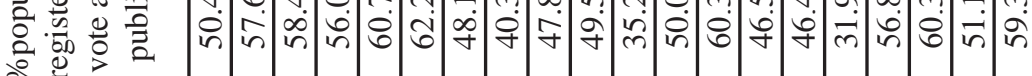

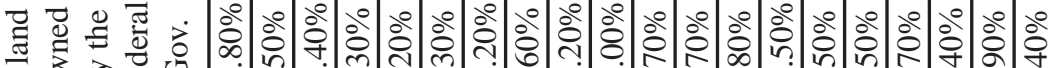

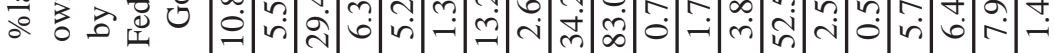

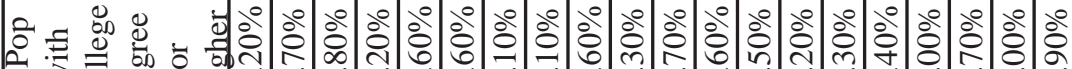

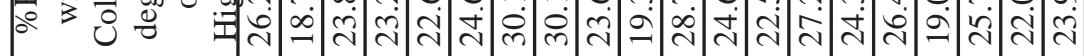

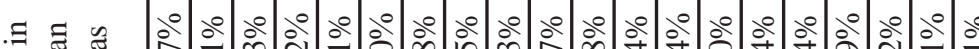

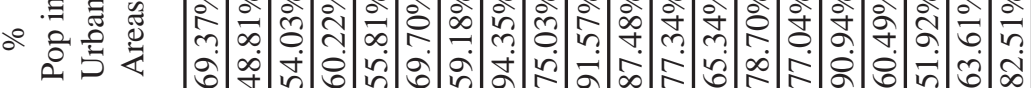

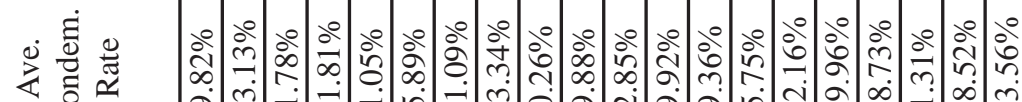

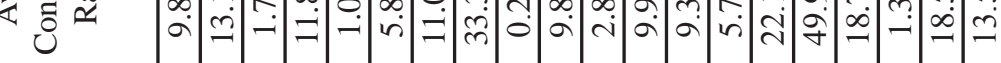

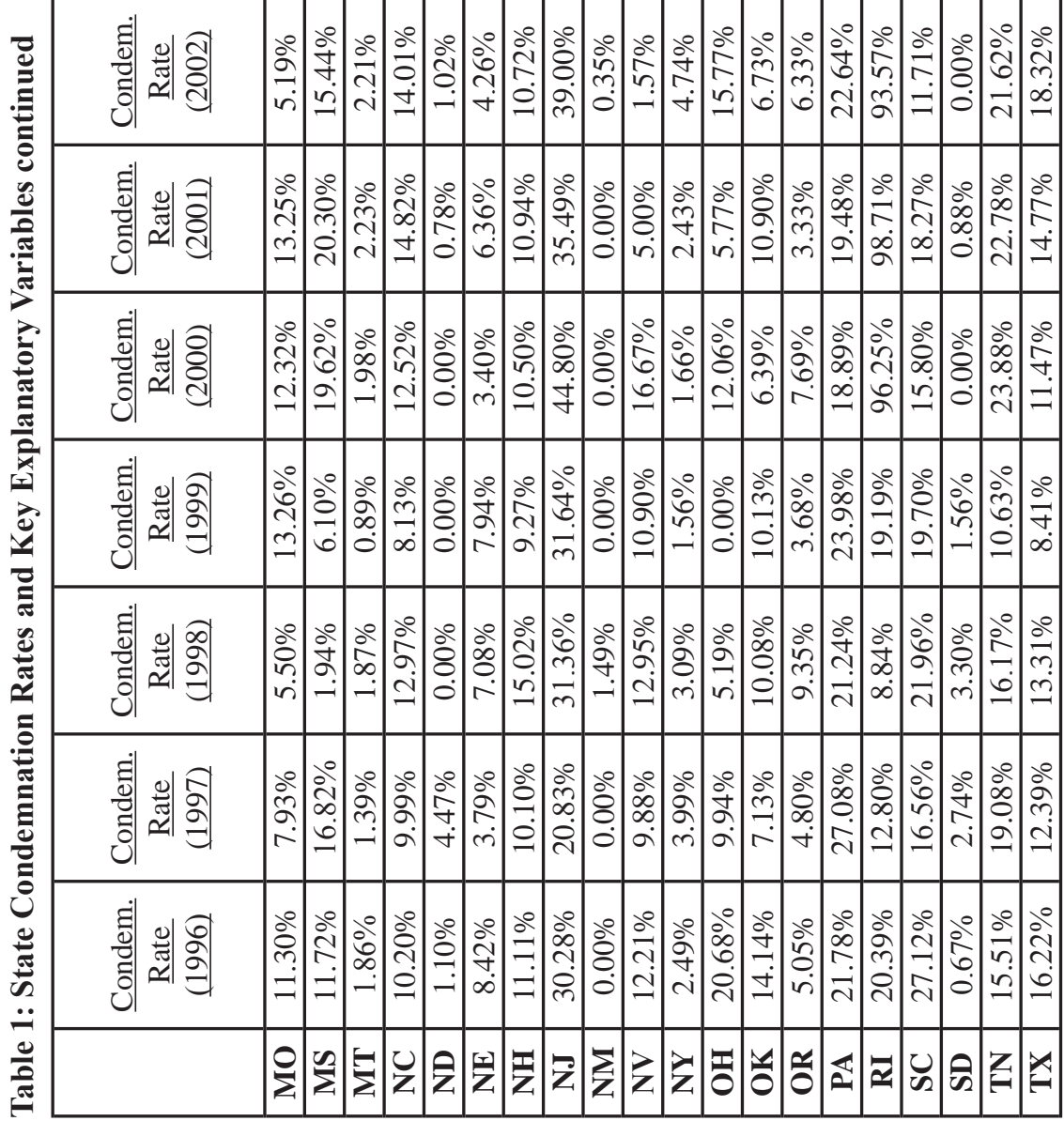




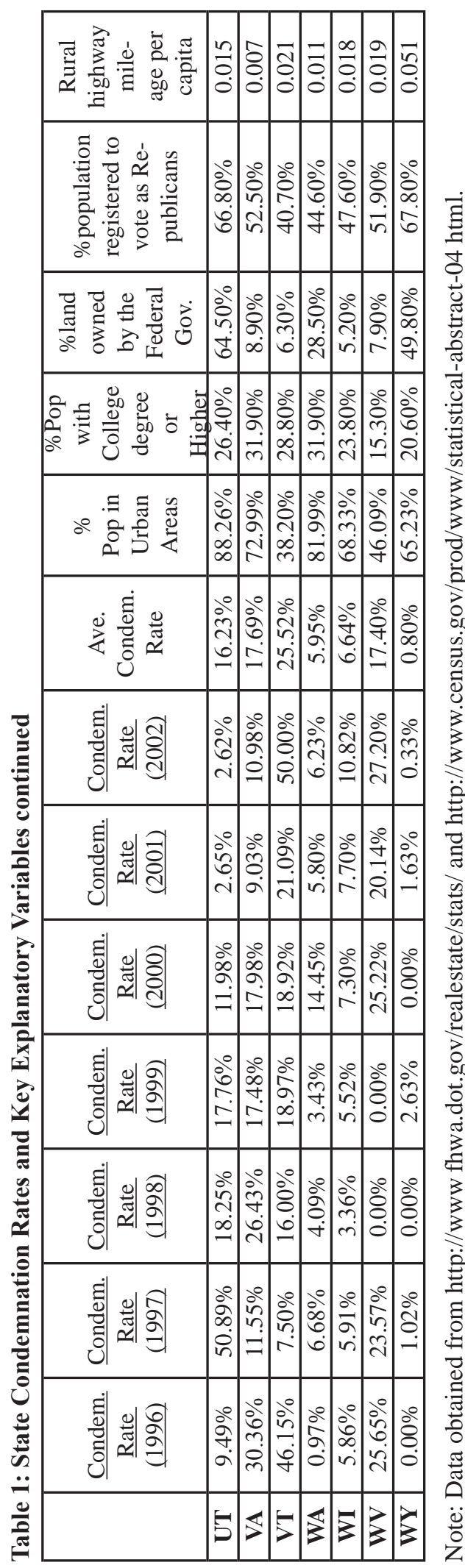

\section{COMPARISON OF STATE LAWS}

As discussed previously, condemnation rates can indicate both the quality of state acquisition practices and the nature of state ROW statutes. State condemnation rates were plotted for years 1996 to 2002 to examine each state's condemnation rate stability over these years (Figure 1). The stability apparent in most states' condemnation rates suggests that something relatively constant and fundamental is at work. While different project corridors are acquired every year, laws tend to evolve rather slowly. These laws constrain acquisition practices. It seems plausible that legal statutes are largely responsible for the condemnation rate stability.

For purposes of analysis, the six-year average condemnation rates were divided into five categories: very low $(0 \%-5 \%)$, low $(5 \%$ $8 \%)$, moderate (8\%-14\%), high (14\%-20\%), and very high (20\%-50\%).This categorization was selected based on significant breaks in average condemnation rates, resulting in a rather natural set of five state clusters (ranging from 9 to 12 states per cluster). Figure 2 provides a histogram of average condemnation rates across states. ROW rules then were compared across clusters to ascertain any general trends or patterns. As mentioned earlier, key acquisition rules were determined through a review of the ROW literature, state laws, and federal rules. These sets of rules were subjected to the following set of questions:

Does state ROW law do the following:

1. allow the acquiring agency to take uneconomic remnants through negotiation and/or condemnation?

2. allow "quick taking"?

3. require the state to pay the owner a portion of litigation costs (if the court awards an amount higher than the "just compensation" previously determined by the agency)?

4. allow an appraisal waiver up to $\$ 10,000$ ?

5. require proof of efforts to reach agreement through negotiation?

6. allow land consolidation?

7. provide comprehensive and detailed laws on compensable items?

8. mandate early public involvement?

9. require the sharing of appraisal and appraisal details with the property owners? 
Right-of-Way Acquisition

Figure 1: U.S State Condemnation Rates (Boxplot of 1996 through 2002 Rates)

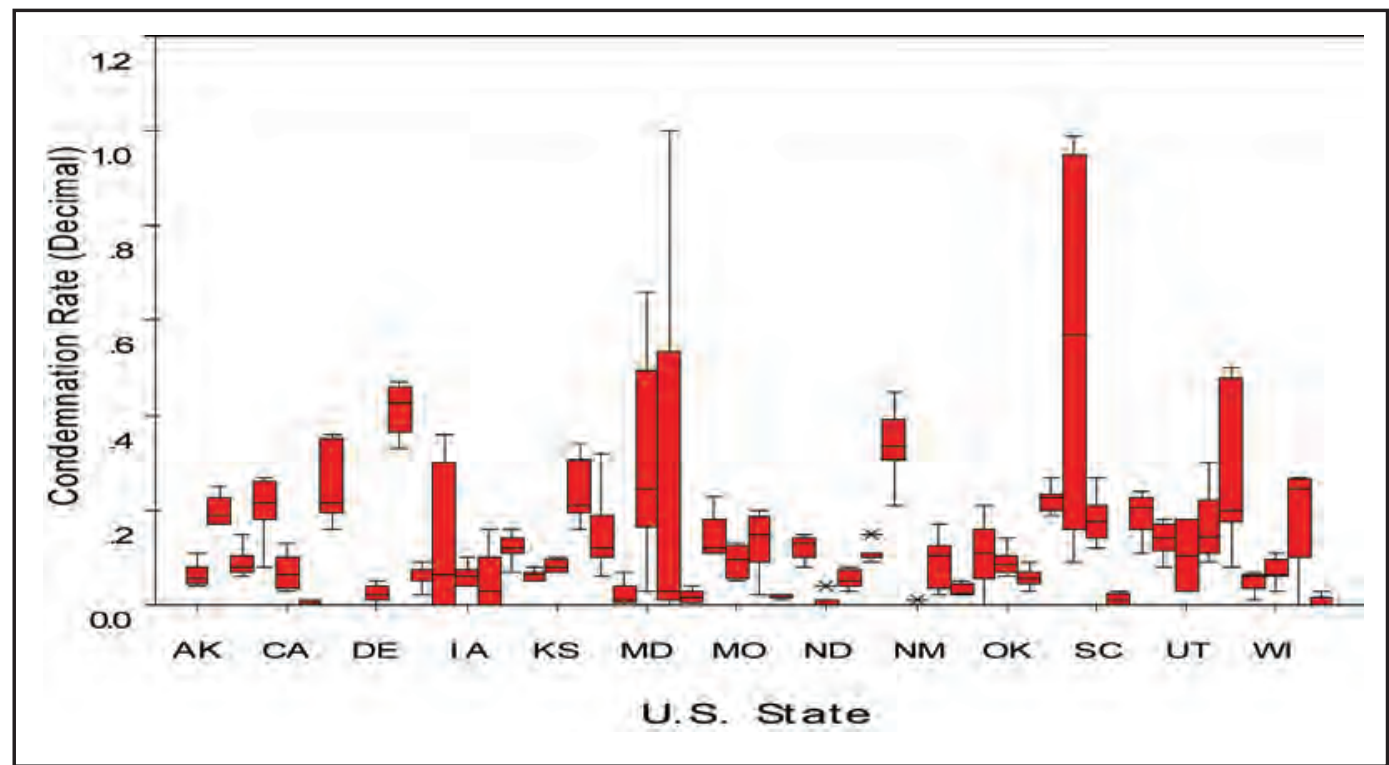

Notes: Names of states are in alphabetical order on the x-axis. Not all state names can be shown, due to space constraints.

Figure 2: Histogram of Average Condemnation Rates Across States

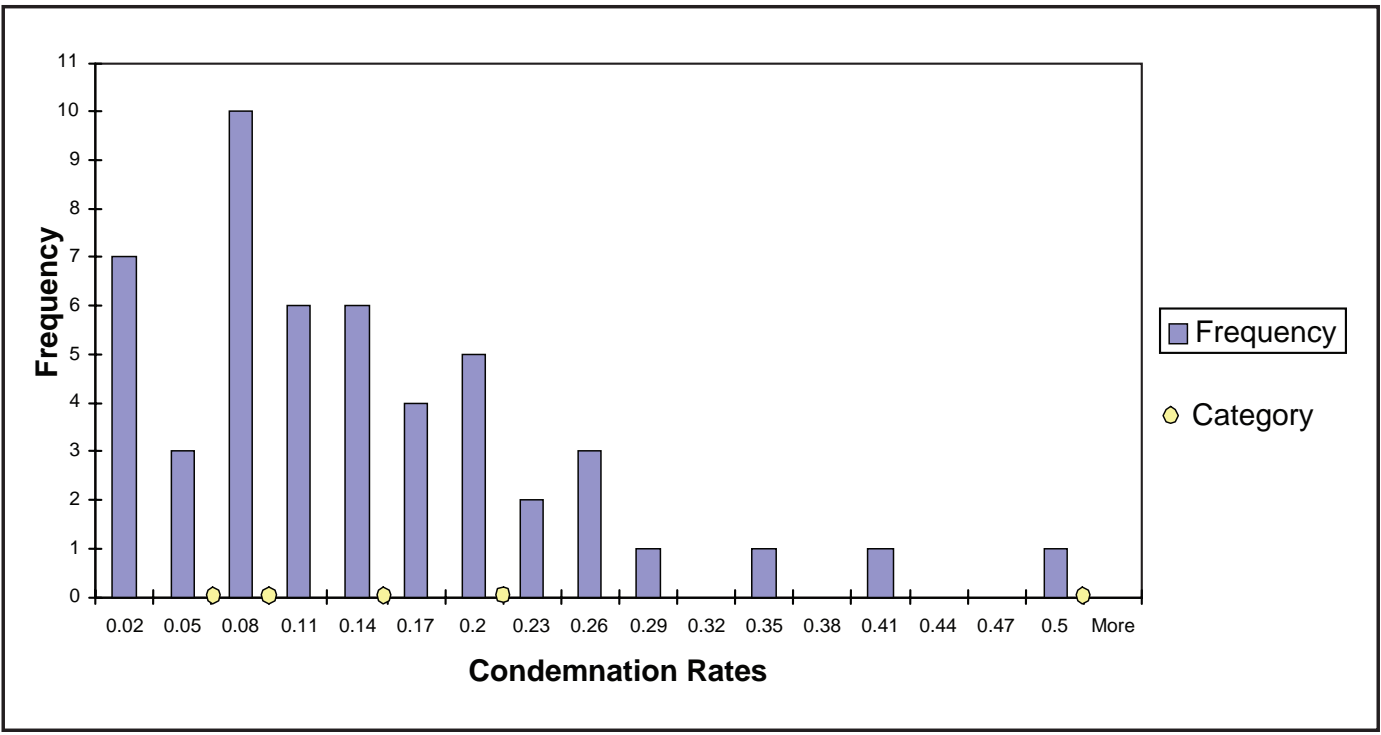


10. encourage meditation and provide reasonable freedom (e.g., administrative settlements and alternative dispute resolution) in using this technique?

11. give property owners more than 30 days to petition against the just compensation offer?

12. allow early taking?

13. allow land exchange?

The percentage of states offering "yes" responses to each question (Table 2) by each condemnation rate category was calculated and displayed in Table 3. These percentages were then studied to ascertain any patterns between state condemnation rates and the key laws suggested by the 13 questions.

The results of this exercise indicate that states that allow quick takings and taking of uneconomic remnants tend to have the highest condemnation rates. Although use of quicktaking techniques can be useful in expediting the ROW delivery when project timelines are tight, it may be abused by ROW administrators. The power of eminent domain in taking remnants also is open to agency abuse. These opportunities for abuse may explain the higher condemnation rates witnessed in those states.

In contrast, states that mandate early public involvement, require sharing of appraisal details, allow early takings, land consolidation, land exchange, emphasize negotiation, encourage flexible methods of mediation, and provide detailed and comprehensive laws on compensable items tend to have the lowest rates of condemnation. Early public involvement allows an agency to predict what design alignments are likely to be problematic when acquiring ROW, thus helping avoid later

Table 2: “Yes” Responses to Key ROW Laws by State

\begin{tabular}{|l|l|l|l|}
\hline State & Questions with Yes Responses & State & Questions with Yes Responses \\
\hline AK & $1,2,9,10,12$ & MT & $2,3,4,5,7,9,10$ \\
\hline AL & $1,4,6,10,12$ & NC & $1,2,4,5,8,9,10,11$ \\
\hline AR & $1,5,8,10$ & ND & $1,2,4,7,8,9,10,12$ \\
\hline AZ & $1,5,6,9,11$ & NE & $4,5,7,9,11$ \\
\hline CA & $1,2,4,7,8,9,10,12$ & NH & $2,4,5,9$ \\
\hline CO & $4,6,7,9,10,12$ & NJ & $2,3,4,5,7,12$ \\
\hline CT & $2,3,4,5,9,10,11$ & NM & $1,2,4,6,8,9$ \\
\hline DE & $1,5,7,9,12$ & NV & $1,6,8,9,10,11,13$ \\
\hline FL & $1,3,4,5,7,8,9,12$ & NY & $2,3,4,5,7,12$ \\
\hline GA & $4,5,6,7,9,11$ & OH & $1,4,5,7,8,9,10$ \\
\hline HI & $1,5,8,9,10$ & OK & $1,2,4,5,6,9,10,13$ \\
\hline IA & $1,5,6,7,8,9$ & OR & $1,4,5,6,8,9,10,11$ \\
\hline ID & $1,2,4,7,9,10,11$ & PA & $2,4,5,7,8,10,12$ \\
\hline IL & $2,4,5,7,8,10,12$ & RI & $1,2,4,7,8,9,10$ \\
\hline IN & $1,6,7,8,9,10,13$ & SC & $1,2,3,4,5,6,9,10$ \\
\hline KS & $1,6,8,9,10,11,13$ & SD & $4,6,7,9,10,12$ \\
\hline KY & $1,5,6,7,8,9$ & TN & $1,5,6,7,8,9$ \\
\hline LA & $2,4,5,7,8,10,12$ & TX & $1,2,4,5,6,9,10,12$ \\
\hline MA & $2,3,4,5,7,12$ & UT & $1,4,5,7,8,9,10$ \\
\hline MD & $1,2,4,7,8,9,10,12$ & VA & $1,5,7,9,12$ \\
\hline ME & $2,4,5,9$ & VT & $2,3,4,5,9,10,11$ \\
\hline MI & $1,2,4,7,8,9,10$ & WA & $1,4,5,6,8,9,10,11$ \\
\hline MN & $2,3,4,5,7,12$ & WI & $4,5,7,9,11$ \\
\hline MO & $1,4,5,6,8,9,13$ & WV & $1,2,4,7,8,9,10$ \\
\hline MS & $1,4,5,6,8,9,12$ & WY & $1,4,5,7,8,9,10$ \\
\hline
\end{tabular}


Table 3. Percentage of "Yes" Responses to Key ROW Laws

\begin{tabular}{|c|c|c|c|c|c|}
\cline { 2 - 6 } & \multirow{2}{c|}{$\begin{array}{c}\text { Very High } \\
\text { Condem. Rate }\end{array}$} & $\begin{array}{c}\text { High Con- } \\
\text { dem. Rate }\end{array}$ & $\begin{array}{c}\text { Moderate } \\
\text { Condem. } \\
\text { Rate }\end{array}$ & $\begin{array}{c}\text { Low Con- } \\
\text { dem. Rate }\end{array}$ & $\begin{array}{c}\text { Very Low } \\
\text { Condem. } \\
\text { Rate }\end{array}$ \\
\cline { 2 - 6 } Question \# & $\begin{array}{c}20 \%-50 \% \\
\text { Rate }\end{array}$ & $\begin{array}{c}14 \%-20 \% \\
\text { Rate }\end{array}$ & $\begin{array}{c}8 \%-14 \% \\
\text { Rate }\end{array}$ & $\begin{array}{c}5 \%-8 \% \\
\text { Rate }\end{array}$ & $\begin{array}{c}0 \%-5 \% \\
\text { Rate }\end{array}$ \\
\hline 1 & $\mathbf{8 5 \%}$ & $75 \%$ & $50 \%$ & $67 \%$ & $12 \%$ \\
\hline 2 & $\mathbf{5 0 \%}$ & $23 \%$ & $32 \%$ & $12 \%$ & $81 \%$ \\
\hline 3 & $15 \%$ & $\mathbf{2 1 \%}$ & $6 \%$ & $18 \%$ & $9 \%$ \\
\hline 4 & $10 \%$ & $2 \%$ & $\mathbf{1 2 \%}$ & $8 \%$ & $11 \%$ \\
\hline 5 & $18 \%$ & $25 \%$ & $26 \%$ & $51 \%$ & $\mathbf{7 6 \%}$ \\
\hline 6 & $34 \%$ & $37 \%$ & $45 \%$ & $52 \%$ & $\mathbf{7 0 \%}$ \\
\hline 7 & $10 \%$ & $15 \%$ & $24 \%$ & $36 \%$ & $51 \%$ \\
\hline 8 & $25 \%$ & $31 \%$ & $35 \%$ & $40 \%$ & $\mathbf{4 6 \%}$ \\
\hline 9 & $23 \%$ & $27 \%$ & $37 \%$ & $43 \%$ & $54 \%$ \\
\hline 10 & $30 \%$ & $41 \%$ & $47 \%$ & $54 \%$ & $\mathbf{7 4 \%}$ \\
\hline 11 & $22 \%$ & $24 \%$ & $32 \%$ & $40 \%$ & $\mathbf{4 4 \%}$ \\
\hline 12 & $4 \%$ & $16 \%$ & $25 \%$ & $20 \%$ & $\mathbf{3 1 \%}$ \\
\hline & $2 \%$ & $6 \%$ & $9 \%$ & $10 \%$ & $\mathbf{1 2 \%}$ \\
\hline
\end{tabular}

Notes: Highest percentage of yes responses to each question are shown in bold. The percentage of states with very high, high, moderate, low, and very low condemnation rates are: $18 \%, 18 \%, 23 \%, 20 \%$, and $21 \%$, respectively.

litigation. The sharing of appraisal details makes the process more transparent, thus enhancing owners trust in agency actions. Early taking of land, if the project plans are known in advance, prevents interim developments and thus reduces cause for later disagreements. Land consolidation and exchange help make properties "whole," thus reducing owner dissatisfaction. Finally, mechanisms for mediation and clear laws on compensation also smooth the acquisition process.

Those states that require payment of litigation costs and give property owners more than 30 days to make a decision tend to fare somewhere in between, in terms of condemnation rates. These two provisions tend to put more power in the hands of the property owners, perhaps allowing for more demands and ability to contest acquisitions.
Legal statutes are one way to evaluate state acquisition processes. Another is a statistical evaluation of other factors, including demographics and land development, as described in the following section.

\section{CONDEMNATION RATE MODEL}

A logistic model of state condemnation rates was developed using FHWA data (http:// www.fhwa.dot.gov/realestate/stats/) and U.S. Census data (http://www.census.gov/prod/ www/statistical-abstract-04.html). This model's specification allows one to predict percentages, where the percentages are the state's average condemnation rates:
(1) $P_{i}=\frac{\exp \left(\beta x_{i}\right)}{1+\exp \left(\beta x_{i}\right)}$ 
where $P_{i}$ represents the percentage of all acquired parcels taken to condemnation in state $i, \beta$ is a vector of parameters to be estimated (via the method of maximum likelihood), and $x_{i}$ is the vector of explanatory variables for state $i$.

A number of available relevant explanatory variables were considered for this analysis. These include population density, income per capita, percentage of urban population, percentage of land owned by the federal government, percentage of registered Republicans, percentage of population with a college degree or higher, and per-capita mileage of various roadways (e.g., urban and rural, major and minor). Because there is no theoretical model of condemnation rates and no a priorii expectation of the relationship of explanatory variables to condemnation rates, a stepwise procedure was used to specify the model. All statistically significant explanatory variables (with p-values less than 0.10 ) were kept in the final model's specification. As shown in Equation 2 and Table 4, the final model controls for the following state characteristics: percentage of population in urban areas (\%UrbPop), percentage of land owned by the federal government ( $\% \mathrm{FedLand})$, percentage of registered Republicans (\%RepPop), percentage of population with a college degree or higher (\%HighDeg), and total rural highway (minor and major) mileage per capita (RurMile/Cap). In other words, the term $\beta x_{i}$ of Equation 1 appears as follows:

$$
\begin{aligned}
& \beta x_{i}=\beta_{o}+\beta_{1}(\% \text { FedLand })_{i}+\beta_{2}(\% \text { RepPop })_{i} \\
& +\beta_{3}(\% \text { HighDeg })_{i}+\beta_{4}(\% \text { UrbPop })_{i} \\
& +\beta_{5}(\text { RurMile } / \text { Cap })_{i}
\end{aligned}
$$

The resulting $\mathrm{R}^{2}$ value is low (.066), as expected. The explanatory variables used in the model are very general and only tangentially related to ROW acquisition. It is the examination of state laws and agency policies that permit a more rigorous inspection of why rates vary across states. Nevertheless, this model illuminates why some states may find it difficult to achieve the same low rates that others have achieved without some fundamental changes in other state attributes.

For example, the coefficient of $\% U r b P o p$ is positive, which indicates that condemnation rates are higher in more urbanized states. This could be due to the fact that urbanization usually means more concentrated residential and commercial properties which typically are more difficult to acquire (than less developed/more rural parcels). The coefficient of the percentage of registered Republicans also is positive. One might conjecture that registered Republicans are less accepting of government intrusion in their lives, via activities like ROW acquisition. The percentage of population with (at least) a college degree also has a positive coefficient, perhaps because such persons are more aware of their legal rights, and are more financially capable of protesting appraisal values and government offers of compensation.

The coefficient of the percentage of land owned by the federal government is negative, as expected. The federal government does not need to deal with private property owners to acquire its own land. The coefficient of total rural highway mileage per capita also is negative, which is possibly because of this variable's positive correlation with rural land

Table 4. Results of Logistic Model of Average Condemnation Rates

\begin{tabular}{|l|c|c|c|}
\hline & Coeff. & t-Statistics & p-value \\
\hline Constant & -2.244 & -3.932 & 0.000 \\
\hline \%land owned by the federal government & -0.01258 & -3.145 & 0.026 \\
\hline \%population registered to vote as Republicans & 0.01961 & 2.345 & 0.066 \\
\hline \%population with a college degree or higher & 0.3294 & 1.978 & 0.106 \\
\hline \%population residing in urban areas & 0.5611 & 3.234 & 0.023 \\
\hline Rural highway mileage per capita & -0.2315 & -3.725 & 0.014 \\
\hline
\end{tabular}

Notes: The District of Columbia was excluded from this analysis due to its constant $0 \%$ condemnation rate. $\mathrm{N}_{\mathrm{obs}}=50$ $\mathrm{LRI}=.066\left(\right.$ pseudo- $\left.\mathrm{R}^{2}\right)$ 
which is generally easier to acquire (than developed land).

\section{CONCLUSIONS}

In recent years, much emphasis has been placed on research in connection with the ROW acquisition process for transportation projects (including reports by the FHWA, NCHRP, AASHTO, and TRB). There is strong emphasis on recognizing best acquisition practices in the U.S. While these various studies contain invaluable information and recommendations, they do not consider the unique legal, environmental, social, political, and economic characteristics of individual states. These qualities are reflected in the state's jurisdictional statutes and constitution, which restrict ROW staff in applying the recommended best practices.

This work compared state statutes for ROW acquisition, noting their associated weaknesses and strengths. It recommended modifications to current laws to expedite the acquisition process, minimize cost, and build property owners' trust in government actions. Additionally, it estimates how various state characteristics impact property condemnation rates.

The results suggest that states should permit their ROW divisions to employ early taking, land consolidation, and land exchange techniques in the acquisition process. In addition, states should not only encourage, but require, their acquiring agencies to engage the public early and report appraisal details to property owners. Finally, more comprehensive and detailed state provisions and laws on compensable items should be sought, as these can significantly smooth the acquisition process.

The statistical model results suggest that more urbanized states face a higher rate of condemnation, undoubtedly because of the presence of more complex and costly properties. Rather interestingly, educational attainment and political party affiliation also were found to play statistically significant roles: condemnation rates rise with education and Republican party affiliation.

Condemnation rates are on the rise nationwide. This work provides some valuable indications as to how legal changes can reduce condemnation rates, and how other factors, not under legislators' control, also play a role.

\section{Endnote}

1. Property owners shall be reimbursed for attorney, appraisal, and engineering fees incurred for condemnation proceedings if the final judgment is that the federal agency cannot acquire the property by condemnation, or the proceeding is abandoned by the United States. In some states, litigation expenses are paid by the acquiring authorities under specific circumstances (FHWA 2004).

\section{References}

AASHTO. The Bottom Line, 2002. URL: http://bottomline.transportation.org (Accessed on 7 May, 2003).

Burnside, J. B. “Implementing Quality in Right-of-Way.” Proceedings of the 2002 AASHTO/ FHWA Right of Way and Utilities Conference, 1996. URL: http://rightofway.transportation.org/ (Accessed on 6 July, 2004)

FHWA. “Acquisition for the 90’s,” 2003. URL: http://www.fhwa.dot.gov/realestate/acq90s.pdf (Accessed on 28 June, 2003).

FHWA.“Project Development Guide,” 2000. URL: http://www fhwa.dot.gov/realestate/pdg.htm (Accessed on 29 July, 2003) 
Kockelman, K.M., J. Jarrett, and J.D. Heiner. “Technical Memorandum: TXDOT Research Project 0-4079: Impacts of Land Use and Land Use Change on Right of Way Cost.” The University of Texas at Austin, Center for Transportation Research, 2003.

Levin, D. R. "Highway Programs and Highway Laws.” Transportation Research Record: Journal of the Transportation Research Board 76 (1963): 5-25.

Lindas, L. I. “Trial Aids in Condemnation Cases.” Transportation Research Record: Journal of the Transportation Research Board 76 (1963): 51-69.

Meltz, R., D. H. Merriam, R.M. Frank. The Takings Issues. Island Press, Inc., Washington D. C., 1999.

NCHRP. "Innovative Practices to Reduce Delivery Time for Right-of-Way in Project

Development,” 2000. URL: http://gulliver.trb.org/bookstore/ (Accessed on 5 July, 2004).

Netherton, R. D. "The Role of Research in Legislative Advocacy.” Transportation Research Record: Journal of the Transportation Research Board 76 (1963):26-37.

U.S. Department of Transportation (USDOT). The Appraisal Guide. FHWA Publication No. FHWA-PD-93-032, 2003. URL: www.fhwa.dot.gov/realestate/apprgd htm (Accessed on 12 December 2003).

U.S. Department of Transportation (USDOT). “Acquiring Real Property for Federal and FederalAid Programs and Projects.” FHWA Publication No. FHWA-PD-95-005, 2002.

U.S. Department of Transportation (USDOT). "Real Estate Acquisition Guide for Local Public Agencies.” FHWA Publication No. FHWA-PD-93-027, 2001.

Shadi Hakimi received a bachelors of science degree in civil engineering from the University of Colorado at Denver in May 2003. She graduated from the University of Texas at Austin with a master's degree in transportation engineering. Ms. Hakimi is currently working for URS Corporation in Austin, Texas.

Dr. Kara M. Kockelman is the Clare Boothe Luce Associate Professor of Civil Engineering at the University of Texas in Austin, and holds a Ph.D., M.S., and B.S. in civil engineering, a masters of city planning, and a minor in economics from the University of California at Berkeley. She presently sits on four Transportation Research Board (TRB) committees and the editorial advisory boards of Transportation Research and the Journal of Regional Science and has been a member of four Cooperative Research Program (NCHRP and TCRP) panels. Kockelman's primary research interests include the statistical modeling of urban systems (including models of travel behavior, trade, and location choice), the economic impacts of transport policy, the incidence and consequence of vehicular crashes, and transport policy-making. She teaches classes in statistics and probability, transportation systems, transport economics, transport data acquisition and analysis, and the geometric design of roadways at UT Austin. 